\title{
LIMNOLOGY OF' FOIX RESERVOIR (BARCELONA, SPAIN)
}

\author{
Rafael Marcé, Marta Comerma, Juan Carlos Garcia, Joan Gomà and Joan Armengol \\ Departament d'Ecologia, Universitat de Barcelona. Avgda. Diagonal, 645, 08028 Barcelona, Spain. Contact \\ e-mail: rafael@porthos.bio.ub.es
}

\begin{abstract}
RESUMEN
El embalse de Foix se caracteriza por un ciclo térmico monomictico, con estratificación durante los meses de verano, aunque sin una capa hipolimnética bien definida. El tiempo de residencia muestra amplias fluctuaciones en concordancia con la irregularidad del flujo entrante, y se situa en valores medios superiores al aiio. Sus aguas son sulfatadas, pudiendose clasificar en el grupo III según Armengol et al. (1991). La concentracidn de nutrientes es muy elevada, destacando la presencia de grandes cantidades de amonio y SRP. Esto permite la presencia de altas concentraciones de clorofila, lo que provoca en última instancia la presencia de una oxiclina durante todo el año, con periodos de anoxia durante la estratificación. El embalse se ha clasificado como hipereutrofico siguiendo los criterios de Carlson (1977) y la OECD (1982). El análisis de componentes principales ha puesto de manifiesto la importancia de los procesos de respiración y fotosintesis en el embalse, asi como el efecto de la actividad humana de la cuenca en la calidad del agua embalsada.
\end{abstract}

Palabras clave: hipereutrofia, estado trdfico, análisis multivariante, ciclo anual, estabilidad térmica

\section{ABSTRACT}

Foix is a monomictic reservoir, with summer stratification and absence of well developed hypolimnion layer: Water residence time has average values higher than one year but shows strong fluctuations matching the large inflow variability. Its sulphated waters can be classified in group III, according to Armengol et al. (1991).Nutrient concentrations are very high, especially ammonia and SRI? These lead to high chlorophyll concentrations, causing a permanent oxicline with anoxic periods during stratification. The reservoir has been classified as hypertrophic according to Carlson (1977) and OECD (1982)criteria. Principal component analyses have shown the importance of respiration and photosynthesis processes, as well as the effect oj human activity on water quality of the reservoir.

Key words: hypertrophy, trophic state, multivariate analysis, annual pattern, thermal stability

\section{INTRODUCTION}

Because of water shortages, also suffered by many Mediterranean countries, more than 1000 reservoirs have been built in Spain during the past century (MOPU, 1988). Considering the scarcity of natural lakes in Spain, reservoirs have centred the interest of Spanish limnologists, as is exemplified by Margalef et al. (1976) work, on one hundred reservoirs, and updated in the early 90's by Morgui et al., (1990); Sabater \& Nolla, (1991); Riera, (1993); Riera et al., (1992); Riera et al., (1991);Armengol et al., (1994);Armengol et al., (1991). Therefore, there is a detailed typology of large Spanish reservoirs. However, the limnology of many small reservoirs remains virtually unknown.

Foix reservoir belongs to this limnologycally unknown group. In fact, little attention has been paid to the reservoir by the scientific community, and it was not included neither in 70's nor 80's surveys (see above). However, since the creation of the "Parc del Foix" by the Diputacio de Barcelona, the situation has changed. Data published from this area concern geological data (Salvadó et al., 1992), animal and vegetal terres- 
trial communities (Herrera et al., 1992) and ciliate littoral fauna (Salvadó 1986, 1993; Salvadó \& Gracia, 1991, 1994). However, with the exception of brief technical reports (Ortiz et al., 1983; Prat et al., 1986; Salvadó et al., 1992), nothing has been published concerning the limnology of the reservoir water body.

The aim of the present work is to describe results obtained between 1995 and 1999, following a limnological control programme on the Foix reservoir. Main objectives of this study are: 1) the description of its thermal cycle and 2) the identification of the present trophic state of the reservoir.

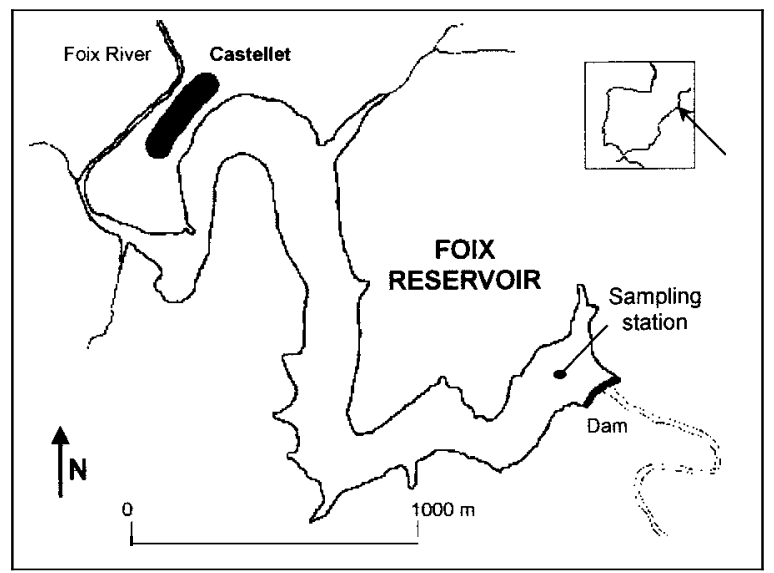

Figure 1. Location and morphometry of Foix reservoir. Situación y morfología del embalse de Foix.

\section{STUDY SITE}

Located in NE Spain (E 1'38'53", N $\left.41^{\circ} 15^{\prime} 21^{\prime \prime}\right)$, at $61 \mathrm{~m}$ above sea level, Foix reservoir collects water from the Foix river, and is the reservoir nearest to the city of Barcelona (Fig. 1). Dammed in 1928 to supply different villages and agricultural fields, nowadays its water is not suitable for human consumption, because of its low quality.

The Penedès plain, drained by the Foix river, has a high agricultural and farm activity, its principle town being Vilafranca del Penedès (50000 inhabitants). The drainage basin is small (31200 $\mathrm{Ha}$ ), and the river runs over a permeable calcareous rock substrate. This, in addition to the considerations mentioned above and a dry Mediterranean climate, makes Foix a temporary river governed by anthropic contributions. It is highly polluted, especially upstream and close to the reservoir (Prat et al., 1985; Prat et al., 1999; 2000).

Foix reservoir can be classified as small and shallow according to Straskraba's classification (Straskraba, 1999) (Table 1). There is only one outlet, at a depth of $8 \mathrm{~m}$ (full reservoir), and an overflow channel on the dam. The basin is situated over calcareous rocks with abundant faults, which in the past allowed an important carstic water circulation, which is now minimised by sediment accumulation. The vegetation is mainly constituted by Pinus halepensis woodland with a sparse population of Quercus ilex. However, on the south slopes it is easy to find well developed shrub communities.

\section{MATERIAL AND METHODS}

The Foix reservoir was sampled at a station near the dam from July 1995 until December 1999 with variable frequency, approximately monthly. Temperature, $\mathrm{pH}$, conductivity, dissolved oxygen and turbidity were measured in situ down the water column each metre with a multiparametric probe Turo Water Analyzer (T-611). Secchi depth was measured with a $20 \mathrm{~cm}$ disc

Table 1. Main morphometric characteristics of Foix reservoir. Características morfométricas principales del embalse de Foix.

\begin{tabular}{lc}
\hline Variable & Value \\
\hline Bottom elevation $(\mathrm{m})$ & 61 \\
Catchment area $\left(\mathrm{m}^{2}\right)$ & $3.12 \times 10^{6}$ \\
Surface area $\left(\mathrm{m}^{2}\right)$ & $7.2 \times 10^{5}$ \\
Max. volume $\left(\mathrm{m}^{3}\right)$ & $5.09 \times 10^{6}$ \\
Max. depth $(\mathrm{m})$ & 11 \\
Mean depth $(\mathrm{m})$ & 7 \\
\hline
\end{tabular}


Table 2. Methods applied for chemical analysis. Métodos utilizados para los análisis químicos.

\begin{tabular}{|c|c|}
\hline Analysis & Method \\
\hline Alkalinity & $\begin{array}{l}\text { Titration with HCI }(0.01 \mathrm{~N}) \\
\text { (Mackereth } \text { et al., 1978) }\end{array}$ \\
\hline Sulphate & Ion chromatography (APHA, 1992) \\
\hline Chloride & Ion chromatography (APHA, 1992) \\
\hline Ammonia & Phenol-hypochlorite (Solorzano, 1969) \\
\hline Nitrate & Ion chromatography (APHA, 1992) \\
\hline Nitrite & Colorimetric (Grasshoff et al., 1983) \\
\hline SRP & Colorimetric (Murphy and Riley, 1962) \\
\hline Total nitrogen & $\begin{array}{c}\text { Alkaline persulphate oxidation } \\
\text { (Grasshoff } \text { et al., 1983) }\end{array}$ \\
\hline Total phosphorus & $\begin{array}{l}\text { Alkaline persulphate oxidation } \\
\text { (Grasshoff } \text { et al., 1983) }\end{array}$ \\
\hline
\end{tabular}

following Margalef (1983) and Hutchinson (1957). Light attenuation was calculated from the data supplied by a Li-Cor probe (Li-193SA with Li-1000 data logger) every $50 \mathrm{~cm}$ down the profile.

Water samples from the reservoir were taken at 0,2 and 5 meters, and at $\mathrm{SO} \mathrm{cm}$ from the bottom, by means of a 5-1 capacity Schindler-Patalas hydrographic bottle. Samples were analysed for alkalinity, sulphate, chloride, ammonia, nitrate, nitrite, SRP and total phosphorus and nitrogen, according to different methodologies described in Table 2. The photosynthetic pigment content of the samples was evaluated spectrophotometrically, applying the trichromatic method (Wetzel and Likens, 1991).

Hydrological data were supplied by the "Agència Catalana de l'Aigua" of the Generalitat de Catalunya (Regional Governement Institution).

\section{RESULTS}

\section{Hydrology}

Figure 2 shows the evolution of the inflow and outflow between 1995 and 1999 in Foix reservoir. The income and outcome volumes were very similar, because of the low regulation capa-

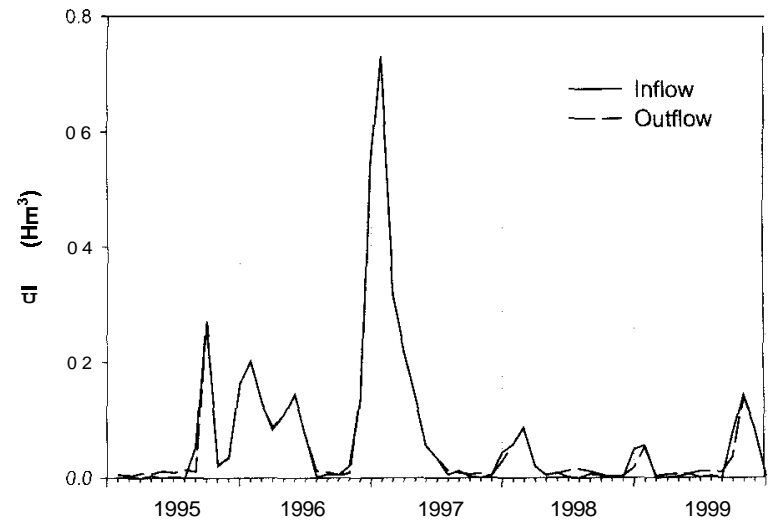

Figure 2. Monthly flows in Foix reservoir. Flujos mensuales en el embalse de Foix

city of the reservoir. Note the strong flow variability, not only in a seasonal pattern, but also in an annual one. The daily volume (Fig. 3) integrates this information, and shows the temporal asymmetry between the processes that fill and empty out the reservoir.

Residence time of the water reached high values (Fig. 4), despite the small volume of the reservoir. With the exception of 1996, residence times were longer than one year, which is the desirable upper limit for this kind of systems (Margalef, 1983). Residence times are also longer than the average of Spanish reservoirs (Margalef et al., 1976). A detailed analysis of this variable highlights its strong seasonal variability (Fig. 4). Periods of fast turnover coincide with rainfall episodes, typically occurring in spring and autumn in the Mediterranean climatic region.

\section{Thermal cycle and stability}

According to the classification in Hutchinson (1957), Foix is a warm monomictic reservoir, with one period of stratification during summer (Fig. 5). Stratification starts in the middle of April, when the surface temperature reaches 11$12^{\circ} \mathrm{C}$, and overturn is in October, after the sinking of the thermocline. The thermocline generally forms around $8 \mathrm{~m}$ depth, coinciding with the outlet depth. 


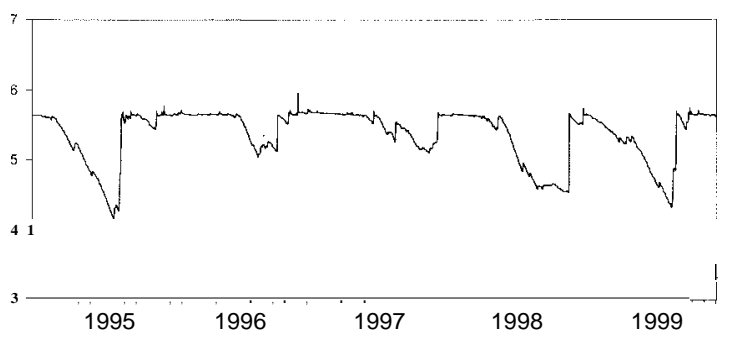

Figure 3. Daily volume in the reservoir. Volumen diario en el embalse

Among various approximations to calculate the thermal stability of a water body, we chose the Brunt-Vaisala frequency, because this parameter has given good results in other similar reservoirs to that on river Foix (Salençon and Thébaulth, 1997; Armengol et al., 1999). For a given temperature profile, thermal stability can be defined as (Imberger, 1979):

$$
\mathrm{E}=1 / \rho \cdot \mathrm{d} \rho / \mathrm{dz}
$$

where $\rho$ is the average density of the layer, $d p$ is the variation of this density and $\mathrm{dz}$ is the layer thickness. If ' $\mathrm{g}$ ' is the gravity acceleration (980 $\mathrm{cm} / \mathrm{s}^{2}$ ), then the Brunt-Vaisala frequency is (Imberger, 1979):

$$
\mathrm{N}=(\mathrm{g} \cdot \mathrm{E})^{0.5}=(\mathrm{g} / \mathrm{\rho} \cdot \mathrm{d} \rho / \mathrm{dz})^{0.5}
$$

Thus, if we consider temperature as the only important factor influencing water density, we deduce water stability will depend only on the degree of stratification $(\mathrm{d} / \mathrm{d} z)$.

Figure 6 shows the evolution of this parameter down the water profile through the period studied. Stability starts rising in April at $4 \mathrm{~m}$. Then, the maximum sinks slowly reaching a depth of 8 $m$ between August and September, when stability is highest. The thermocline collapses in October, and stability remains at its minimum until March.

It can be stated that stratification in Foix reservoir is strong, but temperature profiles during summer are presented as a gradient rather than a well developed thermocline. Therefore, the hypolimnion is not always present. Two antagonistic processes related to water hydrodynamics are acting at this level: while the bottom outflow weakens the stratification (Margalef, 1983; Ford, 1990; Armengol et al., 1996; Han et al., 2000), a long residence time favours it (Han et al., 2000).

\section{Water transparency}

Secchi disc depth ranged between 25 and $120 \mathrm{~cm}$. Minimum values were found in summer. and the
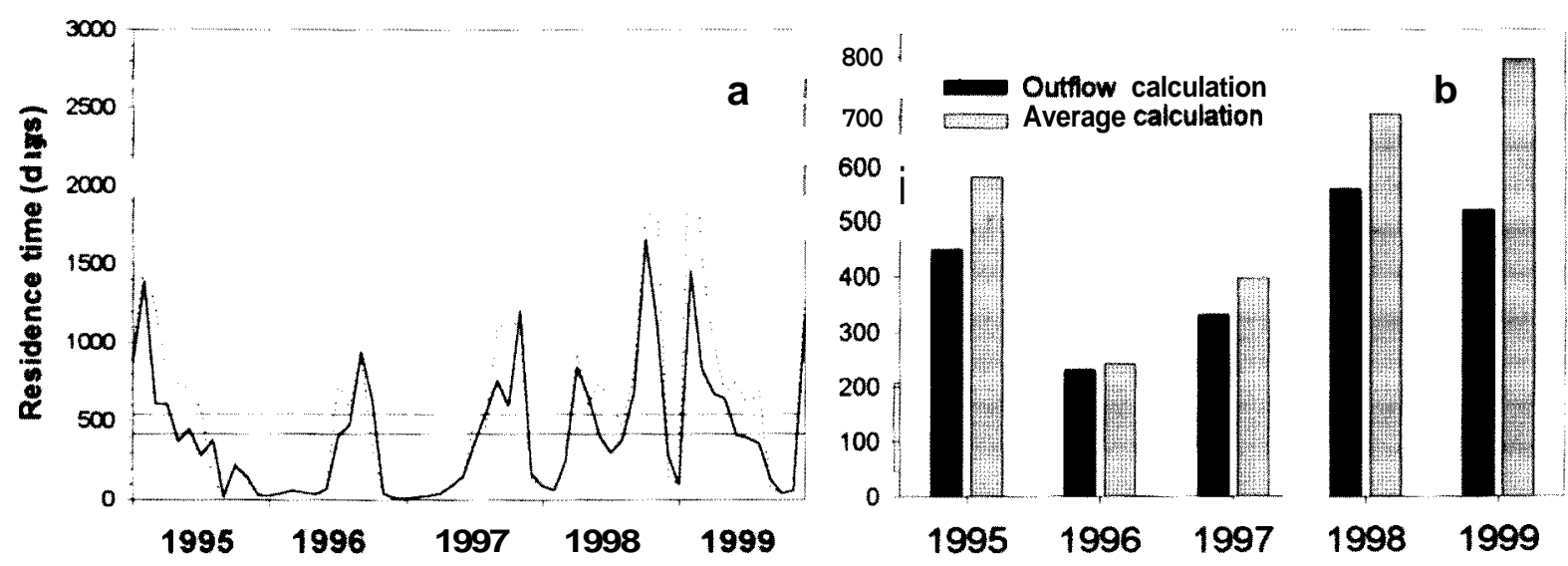

Figure 4. Monthly (a) and annual (b) residence time, calculated from outflow data (unbroken line) and outflow-inflow average (dotted line). Horizontal lines show averages. Tiempo de residencia mensual (a)y anual $(h)$, calculado a partir del flujo de salida (linea continua) y de la media entre el flujo de salida y de entrada (linea punteada). Las líneas horizontales muestrun los valores medios. 

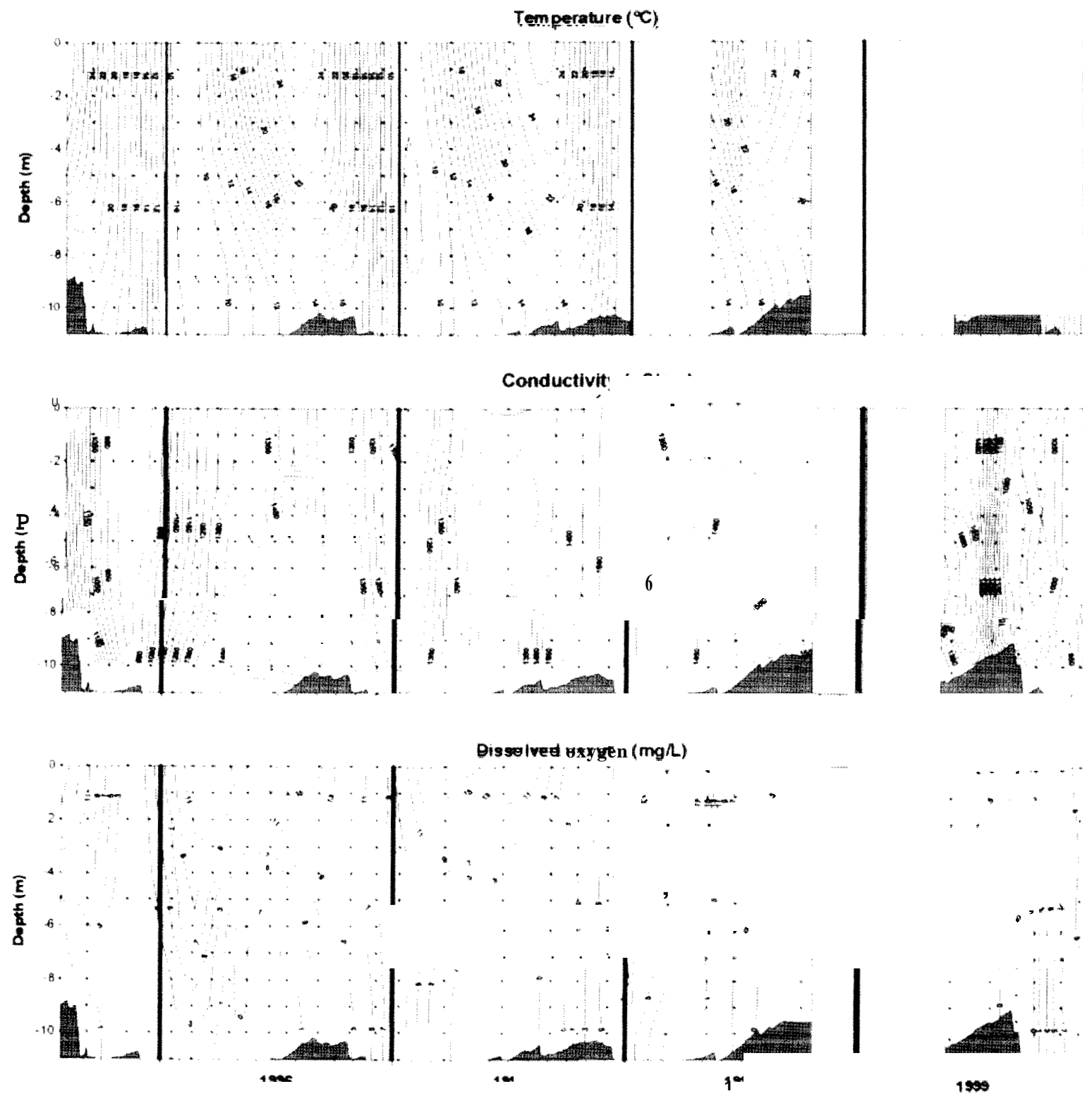

Figure 5. Depth-time plots of temperature, conductivity and dissolved oxygen concentration. Evolución espacio-temporal de la temperatura, conductividad y concentrucidn de oxigeno disuelto.

maximum transparency in autumn. Changes' in light attenuation $(\mathbf{k})$ coincide with this pattern and had a strong exponential correlation with Secchi depth $\left(k=1173.3 \cdot \text { Secchi }_{\mathrm{cm}}{ }_{\mathrm{p}<.0001}\right)^{-1.45} ; \mathrm{r}^{2}=0.75$,

A classical approach to relate Secchi depth and presence of photosynthetic organisms in the water (Carlson, 1977; Ahlgren et al., 1988) was applied. Despite its statistical significance, the exponential relation between Secchi depth and chlorophyll-a concentration was not important $\left([\right.$ Chl $a]=5043 \cdot$ EXP $-\left(0.0334 \cdot\right.$ Secchi $\left._{\mathrm{cm}}\right) ; \mathrm{r}^{2}=0.50$ $\mathrm{p}<0.01)$. The linear relation with light attenuation gave similar results ([Chl $a]=67.41+220 \cdot \mathrm{k}$; 
Temperature $\left({ }^{\circ} \mathrm{C}\right)$
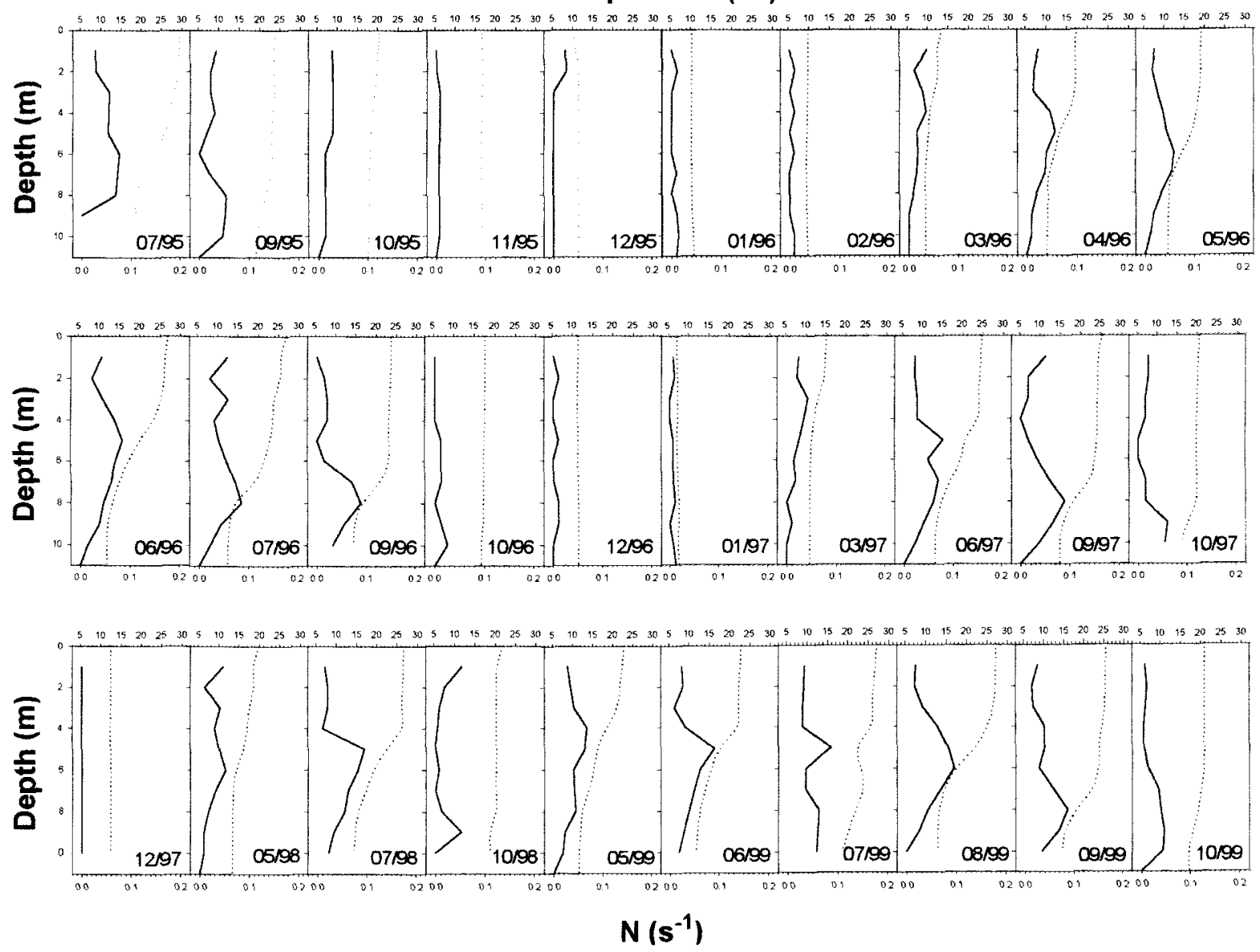

Figure 6. Temperature and stability profiles (expressed as Brunt-Vaisala frequency) in different sampling dates. Perfiles de temperatura y estubilidud (expresada como la frecuencia de Brunt-Väisälä) en diferentes fechus de muestreo.

$\left.\mathrm{r}^{2}=0.54, \mathrm{p}<0.01\right)$. The low correlation can be explained by the presence of detritic organic matter or inorganic suspended solids in the water (Margalef et al., 1976; Lorenzen, 1980; Megard et al., 1980; Margalef, 1983; Soballe \& Kimmel, 1987). At least, this is often the explanation in reservoirs located in the East of Spain (Margalef et al., 1976). This alerts us about the errors that can be made in this kind of water body when using transparency as a trophic state index.

\section{Major ionic composition}

Relative ionic composition of the main components (Fig. 7) establishes the relation SO,' $>\mathrm{CO}_{3}=>\mathrm{Cl}^{-}$, placing the reservoir in group III (dominance of sulphate over bicarbonate) according to the Spanish reservoirs characterisation by Armengol et al. (1991). Reservoirs assigned to this group have sulphated waters with a range of dissolved solids between 400 and 1000 $\mathrm{mg} / \mathrm{l}$, and are spread over a wide area in the East of Spain. Another characteristic of these reservoirs is their sensitivity to eutrophication, as sulphate reduction in anoxic periods indirectly implies the solubilization of iron-combined phosphorus (Margalef et al., 1976; Schindler, 1985; Naselli-Flores, 1999).

Reservoirs are highly variable environments, far from equilibrium in relation to their drainage basin (Margalef, 1983). The large variability in 


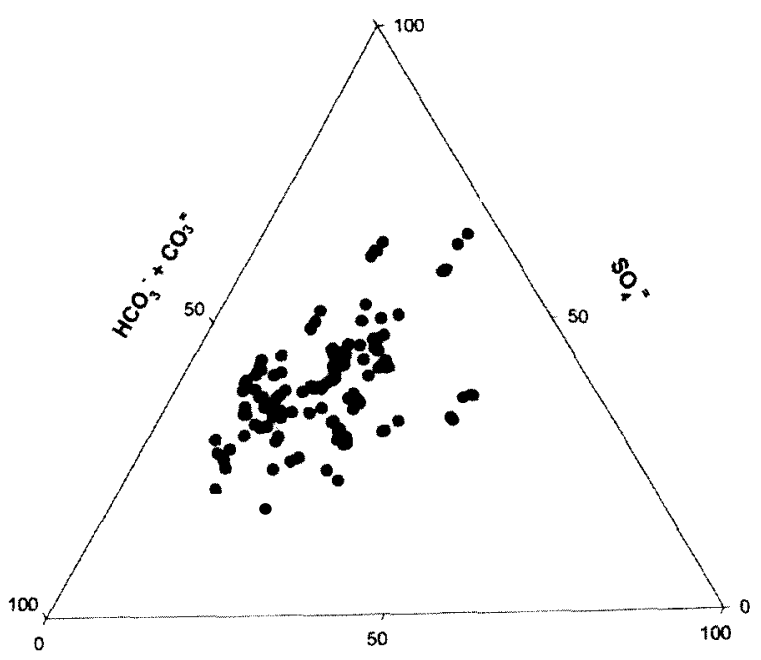

Figure 7. Pipper diagram for the main ionic components. Every depth sampled are shown. Diagrama de Pipper para los componentes ionicos mayoritarios. Se muestran todas las profundidades muestreadas.

concentrations of carbonate and sulphate ions is a good example of this. This variability can be explained by spatial segregation of productionrespiration processes during stratification and seasonal variability of this processes. This agrees with the idea that a typology is not a rigid classification, and natural variability may result in a reservoir being assigned to different groups at different times (Morgui et al., 1990; Riera et al., 1992; Riera, 1993; Armengol et al., 1994).

Absolute values of sulphate range between 160 and $400 \mathrm{mg} / \mathrm{l}$, with the maxima during summer in the epilimnion and minima coincident with rainfall episodes. There are also spatial gradients during stratification, with differences, between surface and bottom, higher than $80 \mathrm{mg} / \mathrm{l}$.

Chloride shows a similar pattern, and ranges between 50 and $500 \mathrm{mg} / \mathrm{l}$. The relation with rainfall episodes is not as strong as in the previous case, mainly because of the linkage between chloride concentration and sewage discharges in the basin (Prat et al., 1999; 2000).

Alkalinity levels are largely explained by carbonate ion concentration in calcareous watersheds, and takes values of $4-5$ meq/l during the mixing period. When stratification starts, however, alkalinity falls in the epilimnion due to photosynthetic processes. In contrast, alkalinity rises in the deep layers. In this way, there are gradients between surface and bottom higher than 6 meq $/ 1$. $\mathrm{pH}$ changes with alkalinity, though with an opposite behaviour. $\mathrm{pH}$ stays at 8 during the mixing period, falling in bottom layers (7.5) and rising near the surface (more than 9) as stratification develops.

\section{Conductivity}

Conductivity is the best variable to explain total content of dissolved ions in the water. This is especially true in Spanish reservoirs belonging to group III according to Armengol er al. (1991), as in these reservoirs conductivity is not well explained by alkalinity (Riera, 1993). Conductivity ranges between 900 and 1700 $\mu \mathrm{S} / \mathrm{cm}$. These values are too high to be explained by Foix watershed drainage, so they can be proof of the anthropic origin of part of the dissolved substances. Spatial distribution of conductivity is strongly affected by flows into the reservoir. The low volume of Foix reservoir makes the distribution of conductivity values very dependent on the inflow regime. In this way, we detected spatial patterns in 1996 (Fig. 5), which was the most humid period, also with the lowest residence time. Spatial structures are specially conspicuous in summer, when the different temperatures between inflow and dammed water allow deep flows. We found these patterns in 1997, but not in 1998 and 1999, years with low precipitation.

\section{Dissolved oxygen}

Dissolved oxygen evolution (Fig.5) shows that there is a permanent gradient in depth through the year. This gradient rises in summer, when the bottom becomes anoxic. There is a surface maximum in spring (17-18 mg/l), although it can move towards summer, as in 1996. From the vertical profiles it can be stated that the oxicline never coincides with the thermocline. The former is always shallower than the latter, so the depth at which production equals respiration is inside the mixing layer. 

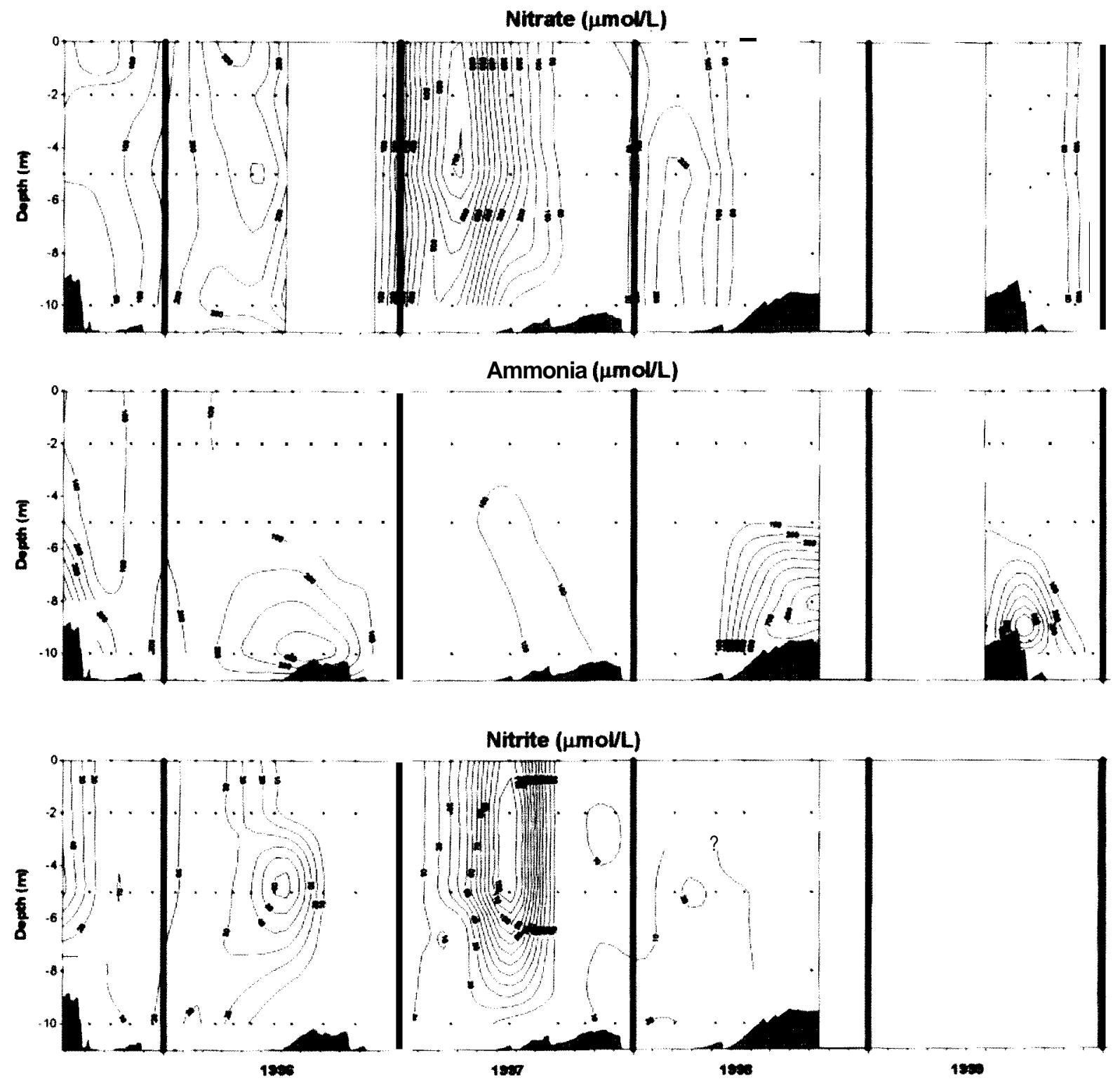

Figure 8. Depth-time plots of nitrate, ammonia and nitrite concentrations. Evolución espacio-temporal de las concentraciones de nitrato, amonio y nitrito.

\section{Nutrients}

\section{Nitrate}

Nitrate concentration in the reservoir follows a clear annual pattern (Fig. 8). Maxima (200-300 $\mu \mathrm{M})$ are in spring, probably due to allocthonous inputs. The concentration then falls to zero in summer, caused by algal assimilation in the epilimnion and reduction processes below this layer, probably with desnitrification episodes. 1997 was an exception, with values higher than $700 \mu \mathrm{M}$. These exaggerated concentrations coincided with 
the highest inflow period in the period studied (Fig. 2), and exemplify the reservoir behaviour during flood episodes, when algal assimilation efficiency is minimal (Elser and Kimmel, 1985).

\section{Nitrite}

Nitrite concentrations are very high (Fig. 8), with maxima between 60 and $120 \mu \mathrm{M}$ during summers 1996 and 1997. These nitrite concentrations are explained by sewage discharges into river Foix upstream, and by the presence of large amounts of nitrate, which cannot be completely reduced into ammonia in production-limited environments (Planas, 1973; Margalef, 1983). Deep nitrite maxima at $5 \mathrm{~m}$ (Fig. 8) are expected in a light-limited environment like that of Foix reservoir (see Water transparency).

\section{Ammonia}

Ammonia concentration in the epilimnion takes values of 30-50 $\mu \mathrm{M}$, whereas in the metalimnion and hypolimnion, when present, concentrations are much higher, reaching between 400 and 900 $\mu \mathrm{M}$ (Fig. 8). Only in 1997, the most humid year among those studied, did ammonia concentrations stay below $200 \mu \mathrm{M}$.

\section{Soluble Reactive Phosphorus}

The most reliable measure of nutrient loads of Foix reservoir is SRP concentration. During the summer values in excess of $70 \mu \mathrm{M}$ were measured in the metalimnion (Fig. 8). In Riera's work on Spanish reservoirs $19.7 \mu \mathrm{M}$ was the maximum value measured (Riera, 1993). Therefore Foix SRP concentrations are exceptionally high. In the epilimnion, values range between 10 and $25 \mu \mathrm{M}$ in winter, descending below $10 \mu \mathrm{M}$ during stratification. High surface values in Autumm 1996 can only be explained by external inputs.

Many authors have considered phosphorus as the key nutrient in eutrophication processes (Dillon et al., 1974; Carlson, 1977; Nurnberg \& Peters, 1984; Elser et al., 1990; Fraile et al., 1995; Reynolds, 1997). The average molecular relationship between phosphorus and nitrogen (DIN:SRP) in Foix reservoir is 11, suggesting phosphorus is the limiting nutrient in Foix reser- voir. However, this average misses spatial variability in both nutrients' concentrations, and must be interpreted with caution.

Total nitrogen and phosphorus Despite its limitations (Perez-Martinez et al., 1991; Reynolds, 1992), total phosphorus has been used as a chlorophyll-a predictor (Vollenweider, 1968; Reynolds, 1992; Riera, 1993). This relation is not clear in Foix. The reservoir has conditions that can interfere with this relationship, mainly low residence times and high non-algal turbidity (Riera, 1993). In theory, total nitrogen is better than total phosphorus as a chlorophyll-a predictor in systems with DIN/SRP $<30$ (Riera et al., 1992), but this assumption is not true in Foix. As some authors remark (Soballe and Kimmel, 1987), and as we will see later for the case of Foix reservoir, chlorophyll-a can be better related to residence time.

\section{Seston}

\section{Chlorophyll-a}

Chlorophyll-a evolution (Fig. 9) shows a consistent annual pattern, with a spring maximum that can be extended until summer (see, for example, 1999). The minima are in winter, when producer communities have temperature and light limitations (Planas, 1973; Riera et al., 1992). Absolute values are extreme, and reach $425 \mathrm{mg} / \mathrm{m}^{3}$ in the surface layers, an exceptional amount of chlorophyll-a taking in consideration Riera's data (Riera, 1993), and also according to Margalef (1983). Expressed as areal concentration, values reach $800 \mathrm{mg} / \mathrm{m}^{2}$ as an average, with maxima over $2000 \mathrm{mg} / \mathrm{m}^{2} .400 \mathrm{mg} / \mathrm{m}^{2}$ can account for the 99\% of the "profitable" fotosynthetic light (Margalef, 1983, 1997). Therefore it is probable that the low ratio between photic zone and mixing depth helps to maintain this amount of pigment, linked to wind-mediated energy inputs (Reynolds, 1997; 1999).

The monthly-average residence time in Foix is never lower than 7 days, a threshold to producers limitation (Kimmel et al., 1990). This only 

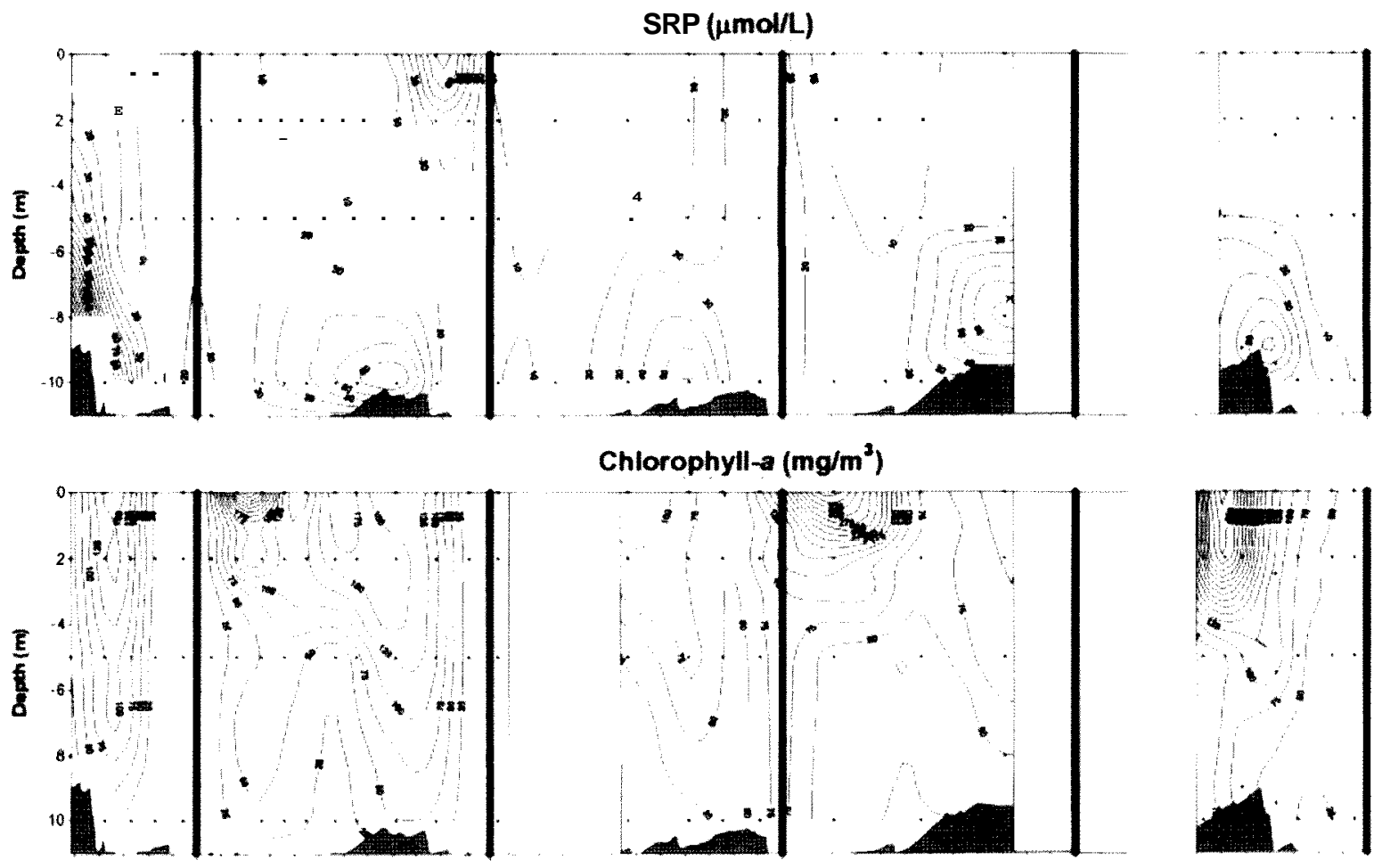

Chlorophyll-a $\left(\mathbf{m g} / \mathbf{m}^{2}\right)$
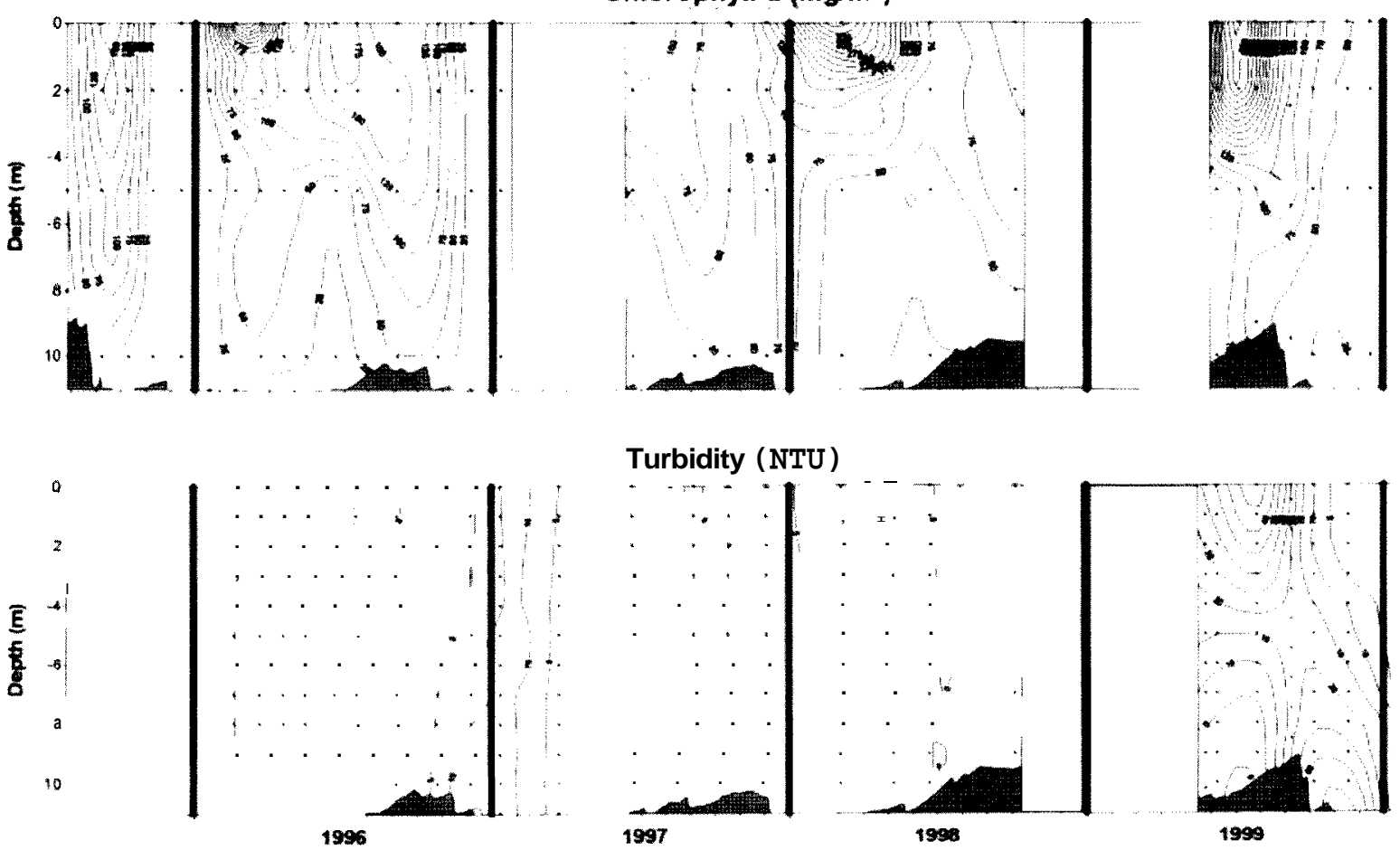

Figure 9. Depth-time plots of SRP, chlorophyll-a, and turbidity. Evolución espacio-temporal del SRP, clorofila-a y turbidez.

occurs during floods, which are episodes in the time-scale of days. It has also been proposed that residence times of lower than 60-100 days have some effect on algal communities (Kimmel et al., 1990; Schutle-Wulwer-Leidig, 1991). These monthly episodes are present in Foix reservoir, especially during the mixing periods of 1996 and 1997, when chlorophyll-a maxima were less important (Fig. 9). Neither turbidity nor nutrient load can explain the differences between these two years and the rest. Therefore, it seems that chlorophyll-a concentrations are closer to residence time than to other factors. This relationship could be direct, as Armengol et al. (1994) found in some Spanish reservoirs, and indirect, due to changes in water hydrology which imply concomitant changes in mixing depth-euphotic depth ratios (Naselli-Flores, 2000). 


\section{Turbidity}

Foix can be classified as a "turbid lake", since turbidity values are rarely zero and commonly rise to over 5-10 ntu (Fig. 9). The evolution of this variable is strongly affected by inflows' turbidity, as is usual in reservoirs (Riera, 1993). High turbidity in 1999 cannot be explained solely by the strong rainfall episodes occurring during this period, in the view of other rainfall episodes of the same magnitude not having similar repercusions over turbidity levels. Rain type, riparian state and edge erosion in the reservoir could help explain these values.

Suspended solids usually have a coating of organic matter (or can be solid organic matter), which can be utilised by consumers (Riera, 1993). Thus, Foix's turbidity leads us to suspect an important heterotrophic pathway in the reservoir.

\section{Multivariate analysis}

The aim of this section is to identify the main patterns of variability in our samples. We have chosen the Principal Component Analysis (PCA), as this technique has been successfully applied to different studies on reservoir limnology in Spain (Margalef et al., 1976; Sabater and Nolla, 1991; Riera et al., 1993). PCA were performed on correlation matrices of log-transformed variables (with the exception of $\mathrm{pH}$ ), which are summarised in table 3 . The confidence of the analysis were tested following the indications found in Legendre and Legendre (1998).

Correlation among variables are shown in Figure 10, as a loading on the first three principal components ( $75 \%$ of total variability). The first axis appears to be positively related to $\mathrm{pH}$, chlorophyll-a, and temperature; and negatively to ammonia, alkalinity, total nitrogen, and SRP.

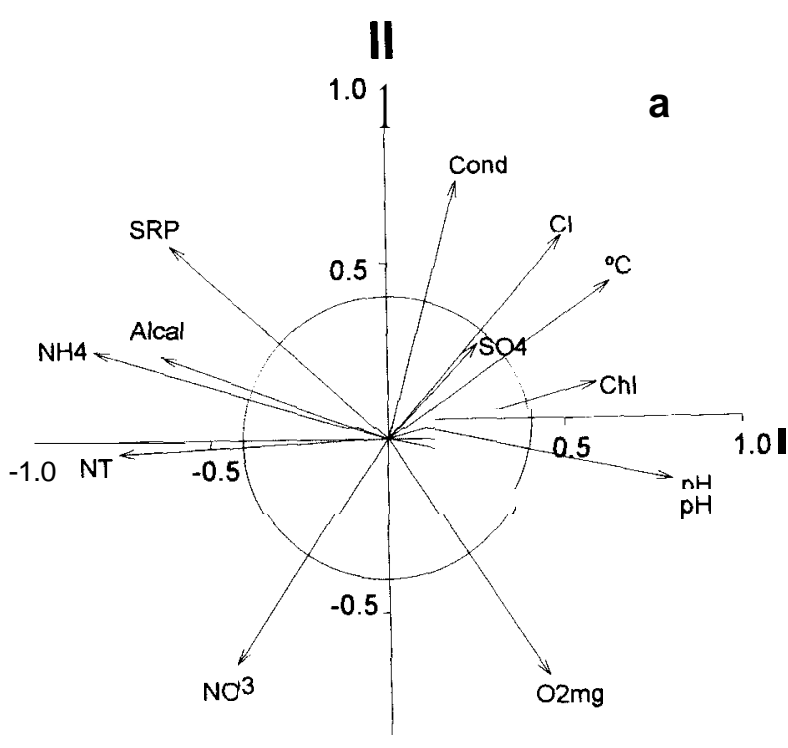

$-1.0$

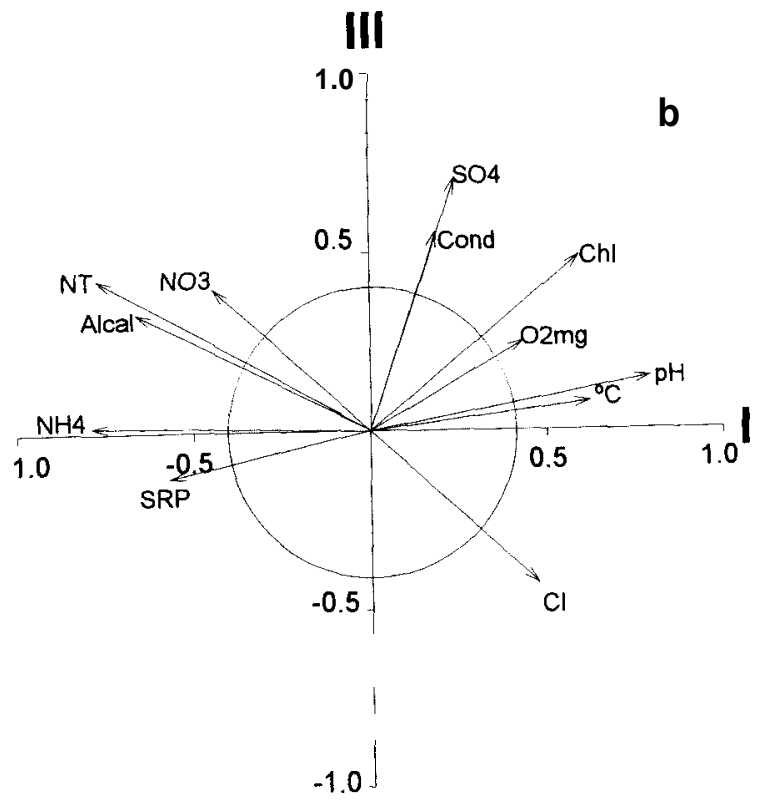

Figure Plot of selected physico-chemical variables in the apace define by (a) the first and second Principal Components and by (b) the first and third ones. Circles mark the points were contributions of deacriptors are in balance. (NO3: nitrate; NT: total nitrogen; NH4: ammonia; Alcal: alkalinity; S R P reactive soluble phosphorus; Cond: conductivity; Cl: chloride; S04: sulphate; "C: temperature; Chl: chlorophylla; O2mg: dissolved oxygen). Distribución de las variables estudiadas en el espacio definido por los dos primeros Componentes Principles (a) y por el primero y tercero (b). Los círculos marcan la contribución equilibrada de los descriptores. (NO3: nitrato; NT: nitrogeno total; NH4: amonio; Alcal: alcalinidad; SRP: fosforo reuctivo soluble; Cond: conductividad; Cl: cloruro; S04: sulfato; "C:temperatura; Chl: clorofila; O2mg: oxígeno disuelto). 
Table 3. Summary statistics for log-transformed variables used to perform the PCA. Estadísticos descriptivos para las variables transformadas logarimicamente utilizadas para el ACP.

\begin{tabular}{lcccccc}
\hline & Average & Variance & Minimum & Maximum & Skewness & \multirow{2}{*}{ Kurtosis } \\
\cline { 1 - 2 } \cline { 5 - 6 } Temperature $(“ \mathrm{C})$ & 2.81 & 0.13 & 2.09 & 3.42 & $-0.1 \mathrm{I}$ & -1.19 \\
pH & 8.24 & 0.34 & 7.02 & 9.57 & 0.18 & -0.26 \\
Diss. Oxygen $(\mathrm{mg} / \mathrm{l})$ & 1.63 & 1.00 & 0.00 & 3.21 & -0.49 & -1.26 \\
Conductivity $(\mu \mathrm{S} / \mathrm{cm})$ & 7.14 & 0.03 & 6.73 & 7.38 & -0.59 & -0.79 \\
Nitrate $(\mu \mathrm{M})$ & 3.45 & 5.64 & 0.00 & 6.12 & -0.56 & -1.43 \\
Ammonia $(\mu \mathrm{M})$ & 3.72 & 2.78 & 0.00 & 6.89 & -0.26 & -0.52 \\
SRP $(\mu \mathrm{M})$ & 2.66 & 0.80 & 0.27 & 5.21 & -0.13 & 2.06 \\
Total nitrogen $(\mu \mathrm{M})$ & 5.85 & 0.39 & 4.59 & 7.18 & -0.31 & -0.56 \\
Chloride $(\mathrm{mg} / \mathrm{l})$ & 4.89 & 0.14 & 4.07 & 5.82 & 0.03 & 0.45 \\
Sulphate $(\mathrm{mg} / \mathrm{l})$ & 5.48 & 0.09 & 4.65 & 6.03 & -0.50 & -0.23 \\
Alkalinity $(\mathrm{meq} / \mathrm{l})$ & 1.70 & 0.11 & 0.36 & 2.40 & -1.24 & 4.31 \\
Chlorophyll-n $\left(\mathrm{mg} / \mathrm{m}^{3}\right)$ & 3.60 & 1.60 & 0.72 & 6.56 & -0.43 & -0.35 \\
\hline
\end{tabular}

The second axis is positively related to dissolved oxygen, conductivity, and nitrate concentration. SRP and chloride also have an important negative load. It seems that two independent processes are affecting variability in the second axis: spatial and temporal variability in redox ambient and inflows affected by human activity. The third axis groups sulphate concentration and conductivity, as water from our reservoir is sulphated. The antagonistic position of chloride again highlights the strong human impact on the reservoir water quality.

The object position in the PCA axes is shown in Figure 11. We have distinguished among surface $(2 \mathrm{~m})$ and bottom $(10 \mathrm{~m})$ samples, in the period between July 1995 and June 1996. The evolution in time of the two layers in the factor III space is orthogonal. Surface samples develop in the first axis, taking positive values in summer and falling below zero at overturn. It is reasonable to relate this evolution to production-respiration processes, nuanced by changes of conductivity (e.g. July 1996), highlighting the importance of human contributions to the inflow. Bottom samples move through the second axis, reaching the highest values during stratification. Respiration and phosphorus mineralization seem to govern the evolution of this layer.
Regarding the third axis, both layers evolve similarly, but changes in surface samples are larger than in bottom ones. The objects reach the highest values in spring, in concert with changes in sulphate concentration.

\section{DISCUSSION}

Eutrophication is the most important environmental problem of dammed water (Fraile, 1995; de Ceballos et al., 1998; Carpenter et al., 1999). Therefore, identification of the trophic state of a water body is one of the key steps to achieve correct management decisions. We have applied the Trophic State Index (TSI) (Carlson, 1977) and the OECD procedure (OECD, 1982), as these are two extensively applied methods over a wide range of situations.

According to the OECD model (Table 4), our reservoir is extremely hypertrophic. TSI values (Table 5), which range from 0 to 100, are exceptionally high, and lead us to the same previous conclusion. The variability in TSI values between different calculation methods is predictable, considering the problems that exist applying this index in reservoirs (Kimmel et al., 1990), as the index was originally designed for use in natural 
, II

Jul-95

a

set-95

Jun-96

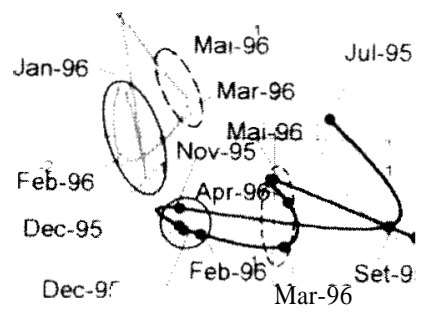

Jan-96

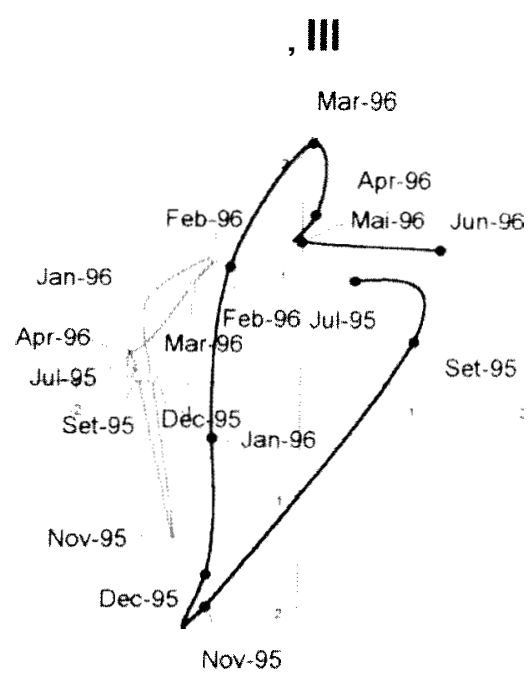

b
II

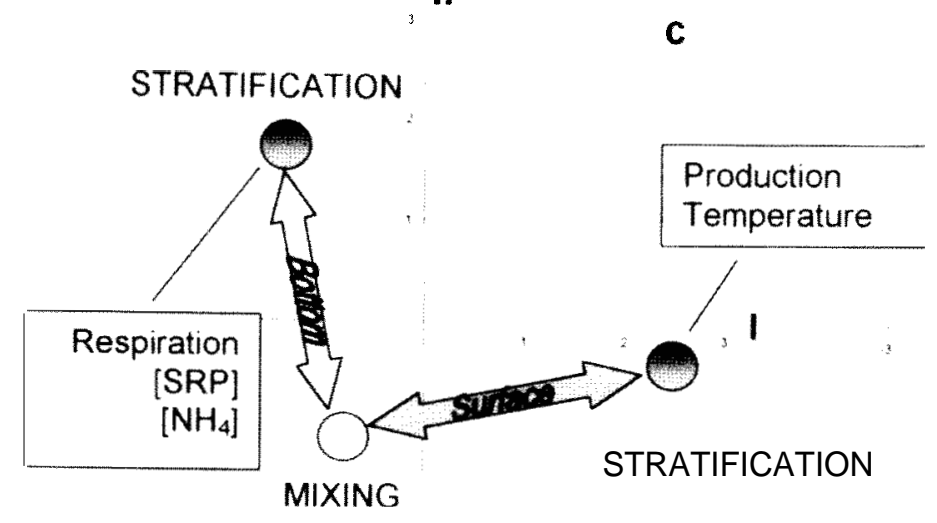

III

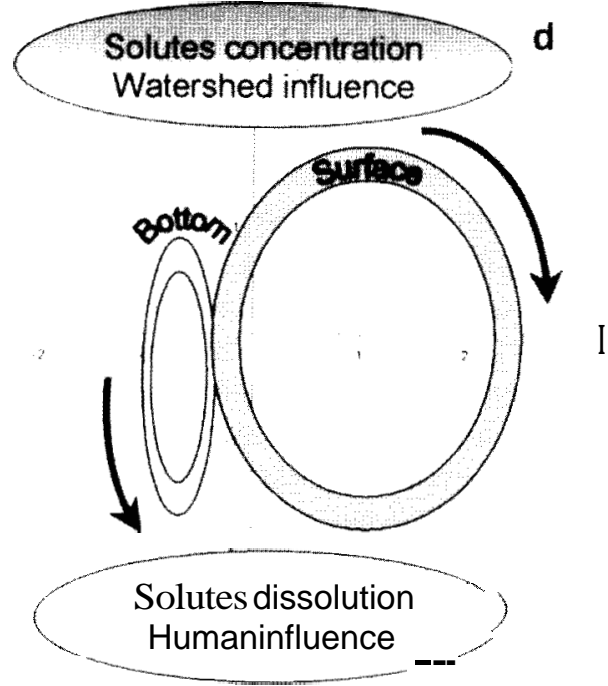

Figure 11. Plot of object distribution in the space defined by (a) the first and second Principal Components and by (b) the first and third ones. Surface layer values (full circles) and bottom layer values (open circles) from July 1995 to June 1996are shown. Circumferences in (a) group together objects from the same period. Conceptual model for the evolution of different layers in the space defined by (c) the first and second Principal Components and by (d) the first and third ones. Distribución de los objetos en el espacio definido por (a) los dos primeros Componentes Principales y por (b) el primero y tercero. Se muestran la capa superficial (circulos oscuros) y la profunda (círculos hlancos), desde Julio de 1995 a Junio de 1996. Las circunferencias en (a) agrupan objetos del mismo periodo. Modelo conceptual paru la evolución de las diferentes capas en el espacio definido por (c) los dos primeros Componentes Principales y por $(d)$ el primero y tercero. 
Table 4. Thresholds to eutrophy and hypertrophy according to OECD (1982), and values found in Foix reservoir (PT total phosphorus; Chl: chlorophyll) in this study. Limites para la eutrofia y la hipereutrofia según OECD (I982), y valores encontrudos en el pantano de Foix (PT: fósforo total; Chl: clorofila) en este estudio.

\begin{tabular}{lcccc}
\hline & $\mathrm{PT}\left(\mathrm{mg} / \mathrm{m}^{3}\right)$ & Chl-a $\left(\mathrm{mg} / \mathrm{m}^{3}\right)$ & Chl-a max. & Secchi $(\mathrm{m})$ \\
\hline Eutrophy & $35-100$ & $8-25$ & $21-75$ & $3-1.5$ \\
Hypertrophy & $>100$ & $>25$ & $>75$ & $<1.5$ \\
Foix & 496 & 136 & $>400$ & 0.6 \\
\hline
\end{tabular}

lakes. Carlson (1977; 1980), Edmondson (1980), Lorenzen (1980), and Megard (1980) have also pointed out to the limitation of Secchi depth as a trophic state predictor in turbid water bodies, as we mentioned above for Foix reservoir (see Water transparency).

A regional criterion (Morgui et al., 1990) proposes a limit between eutrophy and hypertrophy of $50 \mathrm{mg} \mathrm{chl} / \mathrm{m}^{3}$ or $1.0 \mu \mathrm{M}$ SRP. Foix reservoir amply exceeds these limits.

Despite the intrinsic variability of reservoirs, we have tried to deduce patterns from PCA results, stimulated by the slight interannual differences found. Figure 11 represents the conceptual model proposed to explain the changes in water properties of Foix. In the factor 1-11 space the system acts like a spring, returning to the initial state when energy inputs that maintained the system in a stratified-state disappear. These energy inputs allow the surface layers to maintain a high temperature and primary production in sum-

Table 5. Trophic State Index calculated according to Carlson (1977). from minimum, maximum and average values measured in Foix reservoir in this study (PT: total phosphorus; Chl: chlorophyll). Indice de Estado Trófico calculado según Carlson (1977), para los valores mínimos, máximos y promedios medidos en el embalse de Foix en este estudio (PT: fosforo totul ; Chl: clorofila).

\begin{tabular}{lccc}
\hline & Secchi & Chl a & PT \\
\hline Minimum & 63 & 53 & 82 \\
Average & 67 & 79 & 94 \\
Maximum & 81 & 90 & 107 \\
\hline
\end{tabular}

mer, whereas the bottom layers receive this energy indirectly and with less quality, allowing respiration and chemical processes that increase ammonia and phosphorus concentration in deep layers.

The third axis (Fig. 11) marks a solute concentration gradient, with maxima in stratification, when inflows are more concentrated. Values are higher at the surface, since water flows in the epilimnion in summer and redox conditions in depth layers are keep sulphate concentrations low. In autumn, the relative importance of chloride rises, so it is during this period when human activity strongly affects the reservoir.

From the above considerations, it can be stated thet the main characteristic of Foix reservoir is its extreme hypertrophy, helped by long residence times and inflow variability. As we have seen, human activity in the drainage basin has a strong impact on water characteristics. Any management program should take into consideration this factor as essential to improve the reservoir water quality.

\section{ACKNOWLEDGMENTS}

This work has been made possible by the finan$\mathrm{c}^{\mathrm{i}} \mathrm{a}^{1}$ support of Diputació de Barcelona, and it has been partially funded by a project grant of the Spanish Interministerial Commission of Science and Technology (CICYT). The contribution 1999SRG 28 of the Interministerial Commission of Science and Technology (CIRIT) is also greatly appreciated. We are thankful to Agència 
Catalana de l'Aigua for its help and, especially, to the staff of "Parc del Foix". R.M. is grateful to M. Buxadé, Mr. Mackenzie, and D. Balayla for their useful remarks on the English version of the paper.

\section{REFERENCES}

AHLGREN, I., T. FRISK \& L. KAMP-NIELSEN (1998) .Empirical and theoretical models of phosphorus loading, retention and concentration vs. lake trophic state. Hydrobiologia, 170:285-303.

ARMENGOL, J., J. L. RIERA \& J. A. MORGUÍ (1991). Major ionic composition in the Spanish reservoirs. Verh.Internat.Verein.Limnol., 24: 13631366.

ARMENGOL, J., J. TOJA AND A. VIDAL (1994). Seasonal rhythm and secular changes in Spanish reservoirs. In: Limnology Now: A Paradigm of Planetary Problems. R. Margalef (ed.): 237-253. Amsterdam, Elsevier Science B.V.

ARMENGOL, J., M. COMERMA, J. C. GARCÍA, M. ROMERO, J. J. RODRÍGUEZ \& A. VIDAL (1999) . Contribució al coneixement de l'ecologia aquàtica de l'embassament de Sau. Evolucid de l'embassament al 1998.Quaderns ATLL, 2: 1-67

ARMENGOL, J., R. BARTRA, S. SABATER, J. C. GARCÍA \& J. SACRISTAN (1996).Contribución al conocimiento de la ecología acuática del emhalse de Barasona: efecto del dragado del emhalse. Informe para la Confederación Hidrografica del Ebro.

CARLSON, R. E. (1977). A trophic state index for lakes. Limnol. Oceanogr., 22(2): 361-369.

CARPENTER, S. R., D. LUDWING \& W. A. BROCK (1999) . Management of eutrophication for lakes subject to potentially irreversible change. Ecological Applications, 9(3): 751-771.

de CEBAllos, B. S. O., A. KÖNIG \& J. F. de OLIVEIRA (1998).Dam reservoir eutrophication: a simplified technique for a fast diagnosis of environmental degradation. Water Research, 32(11): 34773483.

DILLON, P. J. (1974). The phosphorus-chlorophyll relationship in lakes. Limnol. Oceanogr, 19(5): 767-773.

EDMONDSON, W. T. ( 1980) . Secchi disk and chlorophyll. Limnol. Oceanogr., 25(2): 378-379.

ELSER, J. \& B. KIMMEL (198.5) Nutrient availability for phytoplankton production in a multiple- impoundment series. Can.J.Fish.Aquat.Sci., 42 : 1359-1370.

ELSER, J. J., E. R. MARZOLF \& C. R. GOLDMAN (1990) .Phosphorus and nitrogen limitation of phytoplankton growth in the freshwaters of North America: a review and critique of experimentals enrichments. Can. J. Fish. Aquut. Sci., 47: 14681477.

FORD, D. E. (1990) . Reservoir transport processes. In: Reservoir limnology: ecological prespectives. K. W. Thornton, B. L. Kimmel and F. E. Payne (eds.): $15-$ 41. NY, John Wiley \& Sons.

FRATLE, H., E. ORIVE Y J. POZO (1995) .Evaluación del estado trdfico y comparacidn de modelos relativos al fdsforo en los embalses de Cernadilla y Valparaiso (Rio Tera, Zamora). Limnetica, 11(2): 29-37.

HAN, B., J. ARMENGOL, J. C. GARCÍA, M. COMERMA, M. ROURA, J. DOLZ \& M. STRASKRABA (2000).The thermal structure of Sau reservoir (NE: Spain): a simulation approach. Ecological Modelling, 125: 109-122.

HERRERA, J. A., H. SALVADÓ I T. SALVADÓ (1992). El parc de Foix: Flora, fauna i paisatge. Miscel.lània Penedesenca., 17: 8-67.

HUTCHINSON, G. E. (19.57). A treatise on Limnology. Vol.l:Geography, physics, and chemistry. NY, Wiley.

IMBERGER, J. (1979) . Mixing in reservoirs. In: Mixing in inland and coastal waters. H. G. Fisher, E. J. List, R. C. Y. Koh, J. Imberger and N. H. Brooks (eds.): 148-228. NY, Academic Press.

KIMMEL, B. L., O.T. LIND \& L. J. PAULSON (1990) Reservoir primary production. In: Reservoir limnology: ecological prespectives. K. W. Thornton, B. L. Kimmel and F. E. Payne (eds.): 109-131. New York, John Wiley \& Sons.

LORENZEN, M. W. (1980). Use of chlorophyllSecchi disk relationships. Limnol. Oceanogr, 25(2): 371-372.

MARGALEF, R. (1983) .Limnologia. Barcelona, Ed. Omega.

MARGALEF, R. (1997). Our Biosphere. Oldendorf/Luhe, Ecology Institute.

MARGALEF, R., D. PLANAS, J. ARMENGOL, A. VIDAL, N. PRAT, A. GUISET, J. TOJA Y M. ESTRADA (1976).Limnología de los embalses españoles. Madrid, Dirección General de Obras Hidráulicas. Ministerio de Obras Publicas.

MEGARD, R. O., J. C. SETTLES, H. A. BOYER \& W. S. COMBS (1980).Light, Secchi disk, and trophic states. Limnol. Oceanogr., 25(2): 373-377. 
MOPU (1987) Inventario de presas españolas 1986. Dirección General de Obras Hidraulicas. Ministerio de Obras Publicas.

MORGUí, J. A., J. ARMENGOL Y J. L. RIERA (1990). Evaluación limnologica del estado de los embalses espaiioles: composicidn química y nutrientes. III Jornadas de Presas, Barcelona. 652-668

NASELLI-FLORES, L. (1999) Limnological aspects of Sicilian reservoirs: a comparative, ecosystemic approach. In: Theoretical reservoir ecology and its applications. J.G. Tundisi and M. Straskraba (eds.). Backhuys Pub. Leiden.

NASELLI-FLORES, L. (2000) Phytoplancton assemblages in twenty-one Sicilian reservoirs: relationships between species composition and environmental factors. Hydrobiologia, 424: 1-11.

NURNBERG, G. \& R. H. PETERS (1984). The importance of internal phosphorus load to the eutrophication of lakes with anoxic hypolimnion. Verh. Internat. Verein.Limnol., 22: 190-194.

OECD (1982). Eutrophication of waters: Monitoring Assessment and Control. Paris, Organization for Economic Cooperation and Control.

ORTIZ, J.L. \& R. PENA (1984). Applicability of the OECD eutrophication models to Spanish reservoirs. Verh. Internat. Verein. Limnol., 22: 1521-1535.

PEREZ-MARTINEZ, C., R. MORALES-BAQUERO \& P. SANCHEZ-CASTILLO (1991). The effect of the volume decreasing on the trophic status in four reservoirs from Southern Spain. Verh. Internat. Verein. Limnol., 24: 1382-1385.

PLANAS, M. D. (1973). Composición, ciclo y productividad del fitoplancton del lago de Banyoles. Oecologia aquatica, 1:3-106.

PRAT, N., A. MUNNÉ, C. SOLA, M. RIERADEVALL, N. BONADA $1 \mathrm{G}$. CHACON (1999). La qualitat ecològica del Llobregat, el Besòs i el Foix. Informe 1997. Barcelona, Diputacio de Barcelona.

PRAT, N., A. MUNNÉ, C. SOLA, M. RIERADEVALL, N. BONADA \& G. CHACÓN (2000). La qualitat ecologica del Llobregat, el Besòs, el Foix i la Tordera. Informe 1998. Barcelona, Diputacio de Barcelona.

PRAT, N., G. GONZALEZ, X. MILLET \& M. A. PUIG (1985). El Foix entre l'eixutesa i la contaminacio. Estudis i Monografies, 11. Servei de Medi Ambient. Diputació de Barcelona.

REYNOLDS, C. S. (1992). Eutrophication and the management of planktonic algae: what Vollenweider couldn't tell us? In: Eutrophication: research and application to water supply. D. W.
Sutcliffe and J. G. Jones (eds.): 4-29. Freshwater Biological Association.

REYNOLDS, C.S. (1997). Vegetutionprocesses in the pelagic: a model for ecosystem theory. Oldendorf. Germany, Ecology Institute.

REYNOLDS, C. S. (1999). Metabolic sensitivities of lacustrine ecosystems to anthropogenic forcing. Aquat. Sci., 61: 183-205.

RIERA, J. L. (1993). Regional limnology of Spanish reservoirs. Relationships between nutrients, seston, and phytoplankton. Tésis Doctoral, Universitat de Barcelona. 263 pp.

RIERA, J. L., D. JAUME, J. DE MANUEL, J. A. MORGUÍ \& J. ARMENGOL (1992). Patterns of variation in the limnology of Spanish reservoirs: A regional Study. Limnetica, 8: 111-123.

RIERA, J. L., MARTÍ, E. \& MORGUÍ, J. A. (1991). Changes in the trophic state of the Spanish reservoirs during the last sixteen years. VerhInternat. Verein.Limnol., 24: 1367-1370

SABATER, S. \& J. NOLLA (1991). Distributional patterns of phytoplankton in Spanish reservoirs: First results and comparision after fifteen years. Verh. Internat. Verein. Limnol., 24: 1371-1375.

SALENÇON, M. J. \& J. M. THEBAULT (1997). Modélisation d'ecosystème lacustre. Paris, Masson.

SALVADO, H. (1986). Estudi sistemàtic, faunístic $i$ ecològic dels protozous ciliats d'un embassament fluvial (Emhassament del Foix, Garraf, Barcelona). Tesina de Licenciatura, Universitat de Barcelona. 287 pp.

SALVADO, H. \& M. P. GRACIA (1991). Response of ciliate populations to changing environmental conditions along a freshwater reservoir. Arch. Hydrobiol., 123(2): 239-255.

SALVADÓ, T., E. AYMERICH, H. SALVADÓ, J. A. HERRERA, C. LLOP, S. JORNET \& J. E. PASTOR (1992). Pla Especial de l'embassament del Foix. Ajuntament de Castellet i la Gornal (Barcelona).

SCHINDLER, D. W. (1985). The coupling of elemental cycles by organisms: evidence from whole-lake chemical perturbations. In: Chemical processes in lakes. W. Stumm (ed.): 225-250. New York, John Willey \& Sons.

SCHULTE-WÜLWER-LEIDIG, A. (1991). Water quality aspects of two shallow man-made impoundements with different water residence times. Verh. Internat. Verein. Limnol., 24: 13191323.

SOBALLE, D. M. \& B. L. KIMMEL (1987). A largescale comparison of factors influencing phytoplank- 
ton abundance in rivers, lakes, and impoundments. Ecology, 68(6): 1943-1954.

STRASKRABA, M. (1999) Retention time as a key variable of reservoir limnology. In: Theoretical reservoir ecology and its applications. J.G. Tundisi and M. Straskraba (Eds.). Backhuys Pub. Leiden.
VOLLENWEIDER, R. A. (1968). Scientific fundamentals of the eutrophication of lakes andflowing waters with particular reference to nitrogen and phosphorus asfactors in eutrophication. Paris, OECD.

WETZEL, R. G. \& G. E. LIKENS (1991).Limnological analysis. New York, Springer-Verlag. 